\title{
The Effectivity of Problem-Based Learning Tutor in Achievement of Learning Issue
}

\author{
M. Rifky Ilhami*, Vivi Meidianawaty, M. Edial Sanif \\ Faculty of Medicine \\ Swadaya Gunung Jati University \\ Cirebon, Indonesia \\ *aa.rifky@gmail.com
}

\begin{abstract}
Problem-Based Learning (PBL) is part of the learning process in the competency-based curriculum of Medical Education. In PBL activities, students are given a problem in the form of a scenario, then students will actively discuss to achieve the learning issue. In the discussion, students are guided by a lecturer who serves as a tutor or facilitator. Aim: To analysed the correlation between the tutor's effectiveness and the achievement of learning issue. Method: This research was conducted by an analytic observational method with a cross-sectional design. Retrieval of data by stratified random sampling. The data is then analysed with spearman test. Results: There's a significant correlation between PBL tutor's effectiveness and the achievement overall student learning issue $(p=0.44)$. There's no significant correlation between tutor's effectiveness and the achievement of learning issue in the first and second year students $(p=0.64)$ and $(p=0.206)$, There's a significant correlation between tutor's effectiveness and learning issue achievement in the third year $(p=0.36)$. Conclusion: There's a correlation between the effectiveness of PBL tutors on the achievement of learning issue, but this doesn't have a full effect because there are other factors that influence the achievement of learning issue.
\end{abstract}

Keywords: learning issue, medical education, PBL, tutors

\section{INTRODUCTION}

Problem-Based Learning (PBL) is a student-cantered learning. In this type of learning, students are given a "trigger" in the form of a problem or scenario to determine their own learning issues. Afterward, they do independent learning and return to the group to discuss and improve the knowledge they have acquired [1]. During PBL activities, there is a tutor acted as a facilitator who has a role to facilitate and direct the discussion so that student learning issues can be achieved, but do not intervene directly $[2,3]$. In the previous research by Catur [1] stated that tutors' performance, case / problem quality and prior knowledge of students before the tutorial were very influential factors in the achievement of learning objectives.

Research on the performance of PBL tutors at the Faculty of Medicine of UISU previously showed the results that PBL tutors at FK UISU had high enough performance so that it affected the increase in independent learning activities of FK UISU students. The study also figured out that the average score of independent learning activities and reporting of independent learning outcomes became better if the tutor's performance was also higher [4]. The high average score of independent learning activities will certainly have an impact on the achievement of learning issues that must be achieved by students [4]. The difference between this research with previous research are dependent variable which in the previous research focused on independence learning whereas in this research the dependent variable focused on the achievement of student learning issues.

The Faculty of Medicine at Universitas Swadaya Gunung Jati applies a competency-based curriculum with a Block system using the SPICES approach. So far, the implementation of PBL in the Faculty of Medicine, Universitas Swadaya Gunung Jati has never been evaluated on the extent of the role of tutors in facilitating students in achieving learning issues. Therefore, it is necessary to conduct a research on the effectiveness of the tutor's function in achieving learning objectives in the UGJ Cirebon medical faculty.

\section{MATERIALS AND METHODS}

This study employs an observational analytic research design with a cross-sectional design. The independent variable of this research is the effectiveness of PBL tutors. Meanwhile, the dependent variable is the achievement of learning objectives. Research subjects were 197 students of the Faculty of Medicine at Universitas Swadaya Gunung Jati. The sampling technique is stratified random sampling and uses proportional random sampling. The procedure of this research begins from the request for ethical clearance. Then, it is continued with preparing a research instrument in the form of a questionnaire for tutor performance that has been developed by the faculty and preparing written informed consent. The result from the questionnaire for tutor performance is in the form of score. For the independent variable (the achievement of learning issue) will be collected from OSOCA score data from the academic section of the Faculty of Medicine at Universitas Swadaya Gunung Jati.

\section{RESULTS}

\section{A. Characteristics of Respondents}

Respondents who became the sample of research were students of the Faculty of Medicine at Universitas Swadaya Gunung Jati in the first, second and third years. The first year students consisted of 116 students that were divided into 34 
male and 82 female students. The second year students were 37 students that consisted of 14 male and 23 female students. Lastly, in the third year, there were 44 students consisting of 15 male students and 29 female students.

TABLE I. DISTRIBUTION AND FREQUENCY OF THE NUMBER OF STUDENTS

\begin{tabular}{|l|l|l|}
\hline \multicolumn{1}{|c|}{ Characteristics } & Frequency (n) & Percentage (\%) \\
\hline First Year & 116 & 22.3 \\
\hline Male & 34 & 29.3 \\
\hline Female & 82 & 70.7 \\
\hline Second Year & 37 & 18.8 \\
\hline Male & 14 & 37.8 \\
\hline Female & 23 & 62.2 \\
\hline Third Year & 44 & 58.9 \\
\hline Male & 15 & 34.1 \\
\hline Female & 29 & 65.9 \\
\hline
\end{tabular}

\section{B. Univariate Analysis}

TABLE II. ANALYSIS OF THE EFFECTIVENESS OF PBL TUTORS

\begin{tabular}{|l|l|l|l|l|}
\hline \multirow{2}{*}{$\begin{array}{c}\text { Effectiveness of } \\
\text { Tutors }\end{array}$} & \multicolumn{3}{c|}{ Frequency and Percentage Distribution } \\
\cline { 2 - 5 } & \multicolumn{3}{|c|}{ Effective } & \multicolumn{2}{c|}{ Ineffective } \\
\cline { 2 - 5 } & $\boldsymbol{f}$ & $\boldsymbol{\%}$ & $\boldsymbol{f}$ & $\boldsymbol{\%}$ \\
\hline First year & 75 & 64.7 & 41 & 35.3 \\
\hline Second year & 23 & 62.2 & 14 & 37.8 \\
\hline Third year & 28 & 63.8 & 16 & 36.4 \\
\hline Total & 126 & 64 & 71 & 36 \\
\hline
\end{tabular}

Based on Table 2, it is found that 126 respondents or $64 \%$ stated that PBL tutors at FK UGJ were effective. Meanwhile, 71 respondents or $36 \%$ said that tutors were not effective. From Table 5 it can also be concluded that the most effective number of tutors is in the first year, which is $64.7 \%$. While the number of tutors that was the least effective was in the second year, which was $62.2 \%$.

TABLE III. UNIVARIATE ANALYSIS OF LEARNING TARGET ACHIEVEMENTS

\begin{tabular}{|l|l|l|l|l|}
\hline \multirow{2}{*}{ Students } & \multicolumn{3}{|c|}{ Frequency Distribution and Distribution } \\
\cline { 2 - 5 } & \multicolumn{2}{|c|}{ Above average } & \multicolumn{2}{c|}{ Below average } \\
\cline { 2 - 5 } & \multicolumn{2}{|c|}{$\%$} & \multicolumn{2}{c|}{$\boldsymbol{\%}$} \\
\hline First Year & 73 & 62.9 & 43 & 37.1 \\
\hline Second Year & 29 & 78.4 & 8 & 21.6 \\
\hline Third Year & 27 & 61.4 & 17 & 38.6 \\
\hline Total & 129 & 65.5 & 68 & 34.5 \\
\hline
\end{tabular}

Based on table 3 , it can be seen that the number of students who have grades above the average is 129 students or $65.5 \%$. In contrast, 68 students or $34.5 \%$ have grades below the average. The highest number of students who have grades above the average is in the second year namely $78.4 \%$. It is followed by the first year with $62.9 \%$. Meanwhile, the third year has the lowest number of students who have above the average value of $61.4 \%$.

\section{Bivariate Analysis}

TABLE IV. RELATIONSHIP BETWEEN TUTOR EFFECTIVENESS AND ACHIEVEMENT OF LEARNING ISSUES

\begin{tabular}{|c|c|c|c|c|}
\hline \multirow[t]{2}{*}{ Effectiveness of Tutors } & \multicolumn{2}{|c|}{ OSOCA Value } & \multirow{2}{*}{$\begin{array}{c}P \\
\text { Value }\end{array}$} & \multirow[t]{2}{*}{$\mathbf{r}$} \\
\hline & $\begin{array}{c}\text { Above } \\
\text { average } \\
f f\end{array}$ & $\begin{array}{c}\text { Below } \\
\text { average } \\
\quad f\end{array}$ & & \\
\hline \multicolumn{3}{|c|}{ Effectiveness of First Year Tutors } & \multirow[t]{3}{*}{0,064} & \multirow[t]{3}{*}{0,142} \\
\hline Effective & 51 & 24 & & \\
\hline Ineffective & 22 & 19 & & \\
\hline \multicolumn{3}{|c|}{ Effectiveness of Second Year Tutors } & \multirow[t]{3}{*}{0,206} & \multirow{3}{*}{$\begin{array}{l}- \\
0,139\end{array}$} \\
\hline Effective & 17 & 6 & & \\
\hline Ineffective & 12 & 2 & & \\
\hline \multicolumn{3}{|c|}{ Effectiveness of Third Year Tutors } & \multirow[t]{3}{*}{0,036} & \multirow[t]{3}{*}{0,273} \\
\hline Effective & 20 & 8 & & \\
\hline Ineffective & 7 & 9 & & \\
\hline \multicolumn{3}{|l|}{ Overall Tutor Effectiveness } & \multirow[t]{3}{*}{0,044} & \multirow[t]{3}{*}{0,122} \\
\hline Effective & 88 & 38 & & \\
\hline Ineffective & 41 & 30 & & \\
\hline
\end{tabular}

Based on Table 4, the Spearman correlation test results show that in the first and second years there was no relationship between the effectiveness of tutors and the achievement of learning objectives with a $\mathrm{P}$ value (Significance) respectively of 0.064 in the first year and 0.206 in the second year.

In the third year, the Spearman correlation test results stated that there was a significant relationship between the effectiveness of the tutor and the achievement of learning objectives with a $\mathrm{P}$ value (significance) of 0.036 . The correlation direction of the relationship is positive which means the higher the effectiveness of the tutor, the higher the achievement of learning objectives. Meanwhile the strength of the relationship obtained is weak. This is seen from the value of $r$ obtained, which is equal to 0.273 .

The results of the Spearman correlation test as a whole from the first, second, and third years showed a relationship between the effectiveness of the tutor and the achievement of learning objectives with a $\mathrm{P}$ value (significance) of 0.044 . Meanwhile the direction of the correlation of the relationship is positive which means the higher the effectiveness of the tutor, the higher the achievement of learning objectives. Meanwhile, the strength of the relationship obtained is very low with $r$ 0.122 obtained.

\section{DISCUSSION}

The results of the study found a significant correlation between the effectiveness of tutors and the achievement of learning issues. This is in the same line with the previous research which states that the achievement of learning objectives / learning objectives in the tutorial process is strongly influenced by the tutor's performance, quality of cases / problems and prior knowledge of students before following the tutorial. The strength of correlation in this study is very weak. This may occur because the achievement of learning objectives is not only influenced by the tutor's performance but there are other factors that affect the achievement of student learning issues [1,5-8]. The role of the tutor has a positive influence because the tutor can guide students through the 
learning process, encourage students to reach a deeper level of understanding, ensure that all students are involved in group discussions, monitor the progress of each student, motivate students, and help student groups to deal with problems its interpersonal dynamics [9].

The PBL / Tutorial process can be categorized into two categories namely dynamics group and content discussion. Group dynamics are related to tutorial flow and interpersonal interactions. Whereas content discussion involves the accuracy of tutorial discussion, critical thinking exercises, and the ability to generate hypotheses [10]. The components in the PBL group consist of three important elements, namely students, facilitators, and scenarios. Therefore, in order PBL group discussions can effectively achieve the expected issues, the three elements need to be continuously evaluated, particularly their quality and role [9].

In the learning process using the Problem Based Learning (PBL) method, Barrows and Tamblyn, state that tutors must have expertise in group facilitation (process expert) rather than in the subject area (content expert). Whereas Ross sees the problem-based learning session more as a professional discussion strategy rather than as a teaching session. In Problem Based Learning, tutors facilitate or help all group members to interact by engaging in discussion through existing problems. According to Margetson, tutors do this by asking, identifying, provoking critical thinking, suggesting and giving a problem in a way that helps, but only if necessary [11-14].

\section{CONCLUSION}

From this study, it can be concluded that the majority of tutors who teach the first, second, and third year students of Faculty of Medicine at Universitas Swadaya Gunung Jati have been effective. This is because the number of effective tutors is more than $60 \%$. In addition, most of the students at the Faculty of Medicine UGJ have achieved good learning issues. It is seen from the achievement of OSOCA student scores which reached $60 \%$ above average. So, there is a relationship between the effectiveness of tutors with the achievement of learning objectives.

\section{REFERENCES}

[1] S.S. Catur, "Hubungan Kinerja Tutor Dengan Kegiatan Belajar Mandiri Dan Pelaporan Hasil Belajar Mandiri Dalam Diskusi Problem Based Learning Di Fakultas Kedokteran Universitas Lampung," LOGIKA Jurnal LPPM UGJ, vol. 5, pp. 4, 2011

[2] J. Dent, R.M. Harden, and D. Hunt, A practical guide for medical teachers, Elsevier health sciences, 2017.

[3] G. Erol, M. Berna, A. Gazanfer, and U. Reyhan, "Comparion of knowledge scores of medical students in problem-based learning and traditional curriculum of public health topics," BMC Medical Education vol. 5 , no. 7, 2012

[4] G.R. Rahayu and, O. Emilia, "Pengaruh Kinerja Tutor Terhadap Kemandirian Belajar Mahasiswa dalam Problem Based Learning di Fakultas Kedokteran UISU," Jurnal Pendidikan Kedokteran Indonesia: The Indonesian Journal of Medical Education, vol. 1, no. 3, pp. 193-199. 2012.

[5] S. Shitarukmi, S.R. Projosasmito, and H. Roebertsen, "The effectiveness of pbl problems from students and tutors perspectives," Jurnal Pendidikan Kedokteran Indonesia: The Indonesian Journal of Medical Education, vol. 6, no. 1, pp. 31-43, 2017

[6] O.E. Galib, Hubungan Kinerja Tutor Dengan Kegiatan Belajar Mandiri Dan Pelaporan Hasil Belajar Mandiri Dalam Diskusi Problem Based Learning di Fakultas Kedokteran Universitas Lampung [Tesis]. Jakarta: Universitas Indonesia, 2016

[7] M.M.V.D. Hurk, D.H. Dolmans, I.H. Wolfhagen, and C.P.V.D. Vleuten, "Quality of student-generated learning issues in a problem-based curriculum," Medical Teacher, vol. 23, no. 6, pp. 567-571, 2001.

[8] Konsil Kedokteran Indonesia, Standar Profesi Dokter Indonesia. Jakarta : Konsil Kedokteran Indonesia. 2012.

[9] C.I. Irgananda and T. Widodorini, "Pengaruh Kualitas Skenario Dan Peran Fasilitator Terhadap Keefektifan Diskusi Kelompok ProblemBased Learning," Erudio Journal of Educational Innovation, vol. 4, no. 1, pp. 8-15, 2018

[10] E.C. Noreen, "Theoritical Links Supporting the Use of Problem-Based Learning in the Education of Nurse Practitioner," Nurse Practitioner Education, vol. 29, pp. 6, 2008

[11] G. Maudsley, "Roles and responsibilities of the problem based learning tutor in the undergraduate medical curriculum," BMJ, vol. 318,no. 7184 pp. 657-661, 1999 .

[12] G. Michele, R. Patricia, and O. Peter, "Tutoring in problem-based learning medical curricula: the influence of tutor background and style on effectiveness," BMC Medical Education, vol. 5, pp. 20, 2005.

[13] M.S. Wetzel, "Developing the role of tutor/facilitator. Techniques in medical education: problem-based learning," Postgrad Med J, vol. 72 pp. 474-7, 1996

[14] T. Papinczak, "An exploration of perceptions of tutor evaluation in problem-based learning tutorials," Med Educ., vol. 44, no. 9, pp. 892 899, 2010. 